\title{
AN USHABTI OF THE KING SENKAMANISKEN
}

\author{
Islam I. AMER \\ Faculty of Arts, New Valley University, Egypt \\ E-mail: dreslam_amer@yahoo.com
}

\begin{abstract}
This article deals with one of ushabtis which dates back to the Late period, it was found in Sudan. This paper investigates and studies ushabti of the King Senkamanisken, a king of the kingdom of Kusch who reigned after the Twenty fifth Dynasty. His tomb in Nuri contained many of the different types of ushabtis.
\end{abstract}

\section{KEYWORDS}

Ushabti, Nuri, Kusch, Senkamanisken

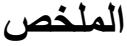

يتتـاول هذا البحـث أحـد تماثيـل الأوشـابتى التـى

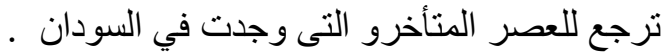

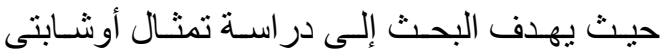
للملك " سنكامنسكن" أحد ملوك مملكة كوش بعد

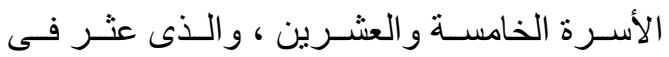

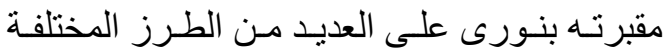

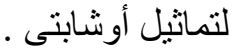
الكلمات الدالة أوشابتى، نورى، كوش، سنكامنسكن

\section{INTRODUCTION}

The excavations of Reisner at Gebel Barkal, Nuri and Meroe (1916, 1919-1923), discovered many archaeological artifacts. ${ }^{1}$ These include many funerary figures which are known with ushabti from the tombs of kings and queens of Napata. In tomb of the King Senkamanisken ${ }^{2}$ at Nuri (Nu.3), at least 410 serpentine and 867 faience ushabtis of different types were found. ${ }^{3}$ Dunham studied the faience ushabti ${ }^{1}$ and divided them into

\footnotetext{
${ }^{1}$ Dunham published the excavations of Reisner at Gebel Barkal, Nuri and Meroë.:see D. Dunham, The Royal Cemeteries of Kush, Published for the Museum of fine Arts by Harvard university press Cambridge, Vol.II Nuri (1955)

${ }^{2}$ The king Senkamanisken (643-623 B.C) one of the kings of Kush, son of Atlanersa (653-643 B.C) see J.U. Beckerath, Handbuch der ägyptischen Königsnamen, ( Berlin 1984), 130;165; D. Dunham and M.F Laming Macadam, "Names and Relationships of the Royal Family of Napata", in : JEA 35, (1949), 147, no.67.

${ }^{3}$ D. Dunham, The Royal Cemeteries of Kush, Vol .II, Nuri, (Boston, 1955), 43.
} 
three types (type 14a, type 14d, type III 2 e). ${ }^{2}$ This paper explores this faience ushabti of the king Senkamanisken. It is preserved in the Museum of the Faculty of Arts, Alexandria University (M.UA.1433). According to the record of this museum, this ushabti is a gift from the government of the Sudan to the Museum. It was found in one of the tombs at Nuri. ${ }^{3}$

\section{DESCRIPTION}

The ushabti statue measures $16,9 \mathrm{~cm}$ high, $4,5 \mathrm{~cm}$ width. It is made of blue faience. The type of this ushabti (fig. 1) is identical to type (III 2 e) (fig.2) which is one of the types of ushabtis of the kings of Napata ${ }^{4}$, in particular the faience ushabti figures, which was found in the tomb of the king Senkamansiken ${ }^{5}$ at Nuri. This ushabti represents the king standing with feet placed together on a rectangular base, wearing a lappet wig without uraeus and plaited beard. The hair is painted black before being glazed. The hands are crossed through the shroud, and the hands protrude on to the chest, like the type H22 (Hands crossed opposite sleeves combined, arms not indicated) which one of the types of hands, which classified by Schneider ${ }^{6}$. The left hand grasps a hoe, while the basket cored in the right hand, the basket or bag itself slinging over the left shoulder. The bag likes also the type B4a (empty bag, segmented wicker-work loops on left shoulder, facing left) which one of the types of bags and baskets which classified by Schneider ${ }^{7}$. A back pillar supports the ushabti.

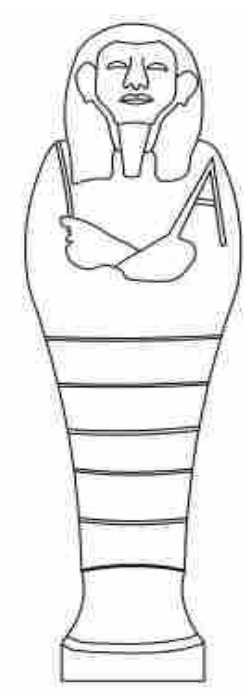

a.

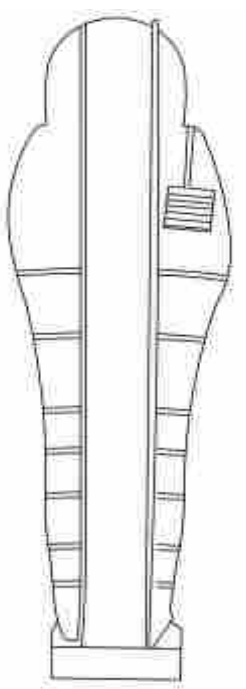

b.

Fig.1 (a, b) ushabti of the king Senkamanisken (M.U.A. 1433), drawing by Researcher.

\footnotetext{
${ }^{1} 540$ faience ushabti and frags of the king Senkamanisken were transferred to many museums, 170 from them in Khrtum 5 in British Museum (55504-55508) 2 in Brooklyn Museum (17-2-1786,1807) 7 in Cairo (46612- 46617, $\frac{23 \mid 6}{2017}$ ) the rest are in Boston . see D. Dunham, Nuri, 285.

${ }^{2}$ D.Dunham, "Royal Shawabti Figures from Napata", in: BMFA 49, No. 276, (1951), 40- 48.

${ }^{3}$ Faculty of Arts, Guide of monuments museum, (Alexandria University, 1950), 133

${ }^{4}$ D.Dunham, BMFA, 49, No. 276, 42; 44-45; D. Dunham, Nuri II , fig. 197; 199; P1.CX1, 14.

${ }^{5}$ The ushabti figures of the king Senkamanisken found mostly scattered about the three chambers, but a few in place against wall of chamber B and chamber C. see. D. Dunham, Nuri II , 43.

${ }^{6}$ H.D. Schneider, Shabtis, An Introduction to the history of Ancient Egyptian funerary statuettes, with $A$ Catalogue of the collection of Shabtis in the National Museum of Antiquities at Leiden, Vol .II, part. I, (Leiden, 1977), 168

${ }^{7}$ H.D. Schneider, Shabtis II ,172.
} 

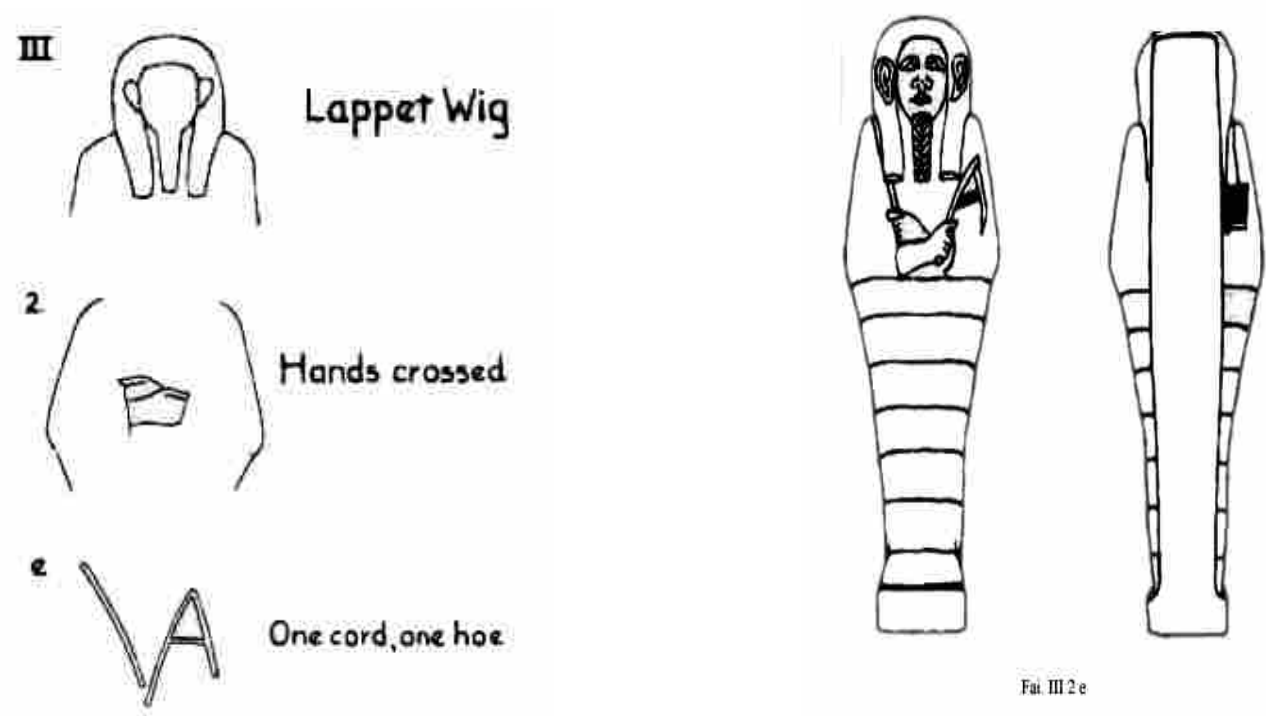

Fig.2 Type III.2.e representing an ushabti of the king in Napata D. Dunham, $B M F A, 49$, no. 276, 42; 44-45

\section{The Ushabti spell}

The front of this ushabti is engraved with a spell, i.e. chapter 6 of the Book of the Dead ${ }^{1}$, in six hieroglyphic horizontal lines. There is a column on the back pillar. They both read from right to left (Figs. 3, 4 a. b., 5 c. d).The text is written in handwriting. Some ideograms are written in inscription close to the Cursive hieroglyphic, especially the signs of men. The text is eroded at the end on the back pillar. It is also noted that the text of this ushabti is identical to the Napata king's ushabti inscriptions; in particular the inscription of type $\mathrm{C}$ which is one of the types of the inscriptions of the king Senkamanisken ${ }^{2}$. This text also contains many passages matching the passages of the version VIIA which is common on the Kushite and Egyptian ushabtis. ${ }^{3}$

\footnotetext{
${ }^{1}$ For chapter 6 from BD See. D.A. Aston,"The shabti box: a typological study",in: OMRO 74 (1994), 2154; L. Bares, and K. Smoláriková, "The Shaft Tomb of Iufaa at Abusir. (Preliminary Report for 1995/96)", in: GM 156 (1997), 9-26; S. Brich, "On sepulchral figures" in: Z̈̈S 2, (1864) 89-96. 103-105; 3 (1865) 4-8. 20-22; J.Capart, " Statuettes funéraires égyptiennes", in: CdE 16 ,(1941) 196-204; F.Chabas, "Observations sur le chapiter VI du ritual égyptien à propos d'une statuette funéraire du Musé de Langres"in: Maspero,G.(Hg),F.Chabas, CEuvres Diverses 2, ( Paris 1902), S.231-247; F.Chabas, "Observations sur le chapiter VI du ritual égyptien à propos d'une statuette funéraire du Musé de Langres"in:Mémoires de la Société Historique et Archéologique de Langres (1863(1862-1877)_Bd.2 Nr.2,S.37-48; J.J.Clére, Une statuette Funéraire( chabti) à formule anormle ,in: Lesko, L.H. ( $\bar{H}$ g.), Egyptological Studies inHonor of Richard A.Parker. Bd.17-21, (Hanover/ London1986); Chr. Noblecourt .Desroches, Amours et fureurs de La Lointaine. Clés pour la compréhension de symboles égyptiens, ( Paris 1995); Van Voss. M. Heerma ,"De sjawabti's en het zandmysterie" in : Phoenix 9 (1963), 53-57; Van Voss. M. Heerma, "On the Meaning of the Shipping of Sand by the Shawabtis", in: Proceedings of the twentysixth international Congress of Orientalists 2 (1968) S. 21; I.Himner, Figurki uszebti , ( Warschau1959); L. Keimer, "Das "Sandfahren" der Totenfiguren (wšbtiw) .. "um den Sand der Ostseite zur Westseite zu fahren": die früheste Erwähnung einer künstlichen Düngung im alten Ägypten" in: $O L Z$ 29 (1926) 98-104;P.E.Lewis, " Is There a Parallel between 1 Samuel 3 and the Sixth Chapter of the Egyptian Book of the Dead?", in: Journal for Study of the Old Testament 31.3, (2007), S. 365-376.

${ }^{2}$ D. Dunham, Nuri II, fig 201. No .8, 257.

${ }^{3}$ H.D. Schneider, Shabtis II.118-119.
} 


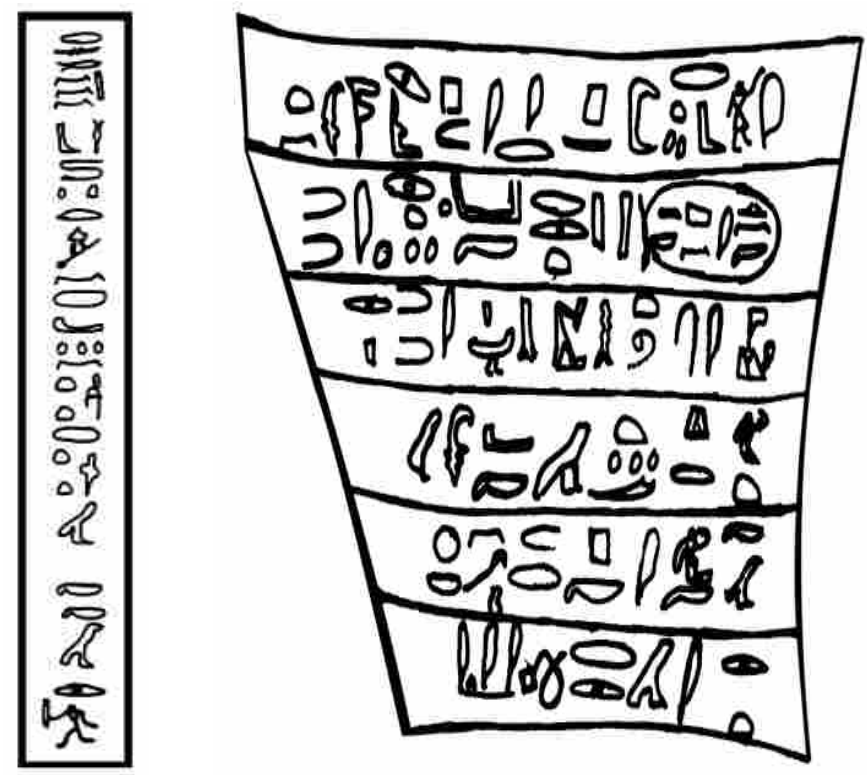

Fig.3 Text spells of ushabti of the king of Senkamanisken (M.U.A. 1433): (Drawing by Researcher)
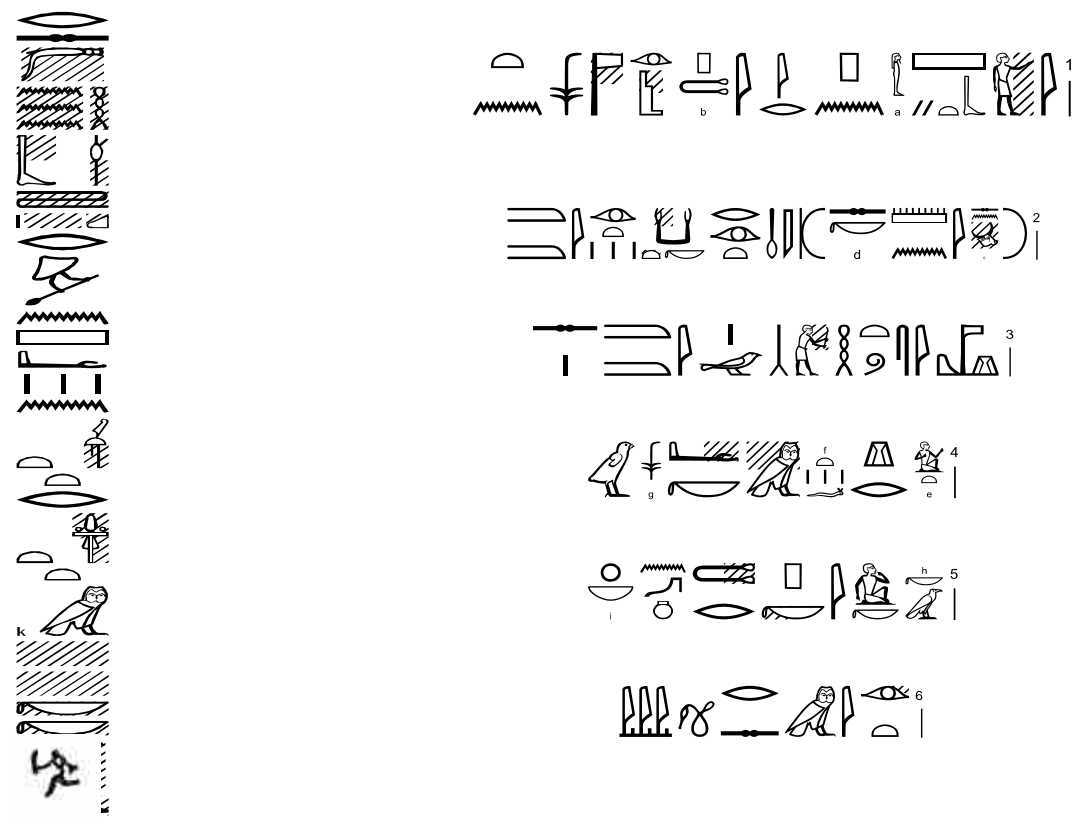

$\bigoplus_{0}^{\mathrm{mmm}} \square$

Ants 0 ant

(1) I šsbty pn ir ip.t (w) ntr Wsir nswt

(2) snk Imn $s k(n) m 3^{\top}$ hrw r ir.t $k 3(w) t . k$ ir.t imm

(3) hrt-ntr istw ḥw imm s

(4) $t$ ?(r) hrwt.f $m k s w$

(5) k’i. $k$ ip.k $\underline{t}$ (?) $r n w n b$

(6) irt im $r s(r) d s h w t$

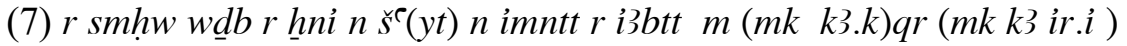

\footnotetext{
- 38 - An Ushabti of the King Senkamanisken
} 


\section{TRANSLATION AND COMMENT}

\section{Translation:}

(1) $O$, this shabti ${ }^{(a)}$, if one counts ${ }^{(b)}$ off the deceased, the King

(2) Senkamanisken ${ }^{(\mathrm{c}, \mathrm{d})}$ justified to do your work in

(3) cemetery, now indeed obstacles are implanted there with as

(4) a man $^{(\mathrm{e})}$ at his duties ${ }^{(\mathrm{f})}$, here he ${ }^{(\mathrm{g})}$

(5) is you shall say ${ }^{(\mathrm{h})}$,you are counted off,(?) at any time ${ }^{(\mathrm{i})}$

(6) to serve there, ( to make) arable a field,

(7) to irrigate a riparian land, to transport by (boat) the sand from the west to the East , ${ }^{(k)}$ (here you, you shall say) or ( here, I am shall say and doing). ${ }^{1}$

\section{COMMENT:}

(a) In the text Type $\mathrm{C}$, the word $̌ 3 b t y$, was written with the determinative of $\mathrm{s}^{2}$, but in the text of the ushabti of Alexandria, it is written with the determinative of $\rrbracket^{3}$. This determinative was attested in many texts for the word of ushabti ${ }^{4}$. The word of ushabti was also written in some Kushite texts as follows: the word šbty was written in a singular form, followed by a masculine singular demonstrative pronoun $p n$, This occurs rarely on the ushabtis of the Late Period, on which

\footnotetext{
${ }^{1}$ Cf. CT. 472. See. A.de Buck, CT VI, 1-2; R.F. Faulkner, The Ancient Egyptian Coffin Texts, Vol II, (London 1977), 106. Cf. BD. Chapter .6 E. A. W Budge, The Book of the Dead. An English Translation of the Chapters, Hymns, etc., of the Theban Recension, with Introduction, (London 1951), Vol .I, 2829;R.O.Faulkner, The Ancient Egyptian Book of the dead, (London 1993), 36; P.Barguet, Le liver des morets des Anciens Egyptiens, introduction, traduction, commentaire, (Paris 1967), Translation by Zaika Tabozada, (Cairo 2003),37. Cf. H. Kees, Religionsgeschichtliches Lesebuch, Band 10, (Tübngen 1928), 53, n.96. Also.See. A.Piankoff, " Deux variantes du chapitre VI du "Livre des Morts" sur les ouchabtis, in: ASAE 49 (1949), 169-170; H. A.Schlögl, and A. Brodbeck, Ägyptische Totenfiguren aus öffentlichen und privaten Sammlungen der Schweiz, Freiburg (Schweiz 1990); H. A.Schlögl, and Chr. Meves-Schlögl, Uschebti. Arbeiter im ägyptischen Totenreich, (Wiesbaden 1993); H. A.Schlögl, And M. Sguaitamatti, Arbeiter des Jenseits. Ägyptische Totenfiguren (Uschebtis),Bd.2 : Zürich Archäologische Hefte,,(Zürich, 1977); D. Spanel, "Donald, Notes on the Terminology for Funerary Figurines", in: SAK 13 (1986), 249253; L.Speleers, Les figurines funéraires égytiennes , ( Brüssel 1923); P.vernus, "Une formule des shaouabtis sur un pseudo-naos de la XIIIe dynastie", in: RdE 26 (1974), 100-114; F. Welc, "A Fragment of a Shabti from Thebes" ,in: GM 145 (1995), 95-99; V. Wessetzky, "Die Uschebti-Formel des "Sandfahrens" und die Himmelsrichtungen", in: MDAIK 37 (1981), 493-496; J .Černý, " Le caractère des oushebtis d'après les idées du Nouvel Empire", in : BIFAO 41 (1942) 105-133.

${ }^{2}$ D. Dunham, Nuri II , fig 201., no .8 , 257. See. A. H. Gardiner, Egyptian Grammar, Begin and introduction to the Study of Hieroglyphs, third edition, (London, 1973), Sign-list. B.1, 544.

${ }^{3}$ A. H. Gardiner, Egyptian Grammar, Sign-list. A.53, 544.

${ }^{4}$ See. $W b$ VI, 410;N. Reeves, "An Unpublished Royal Shabti of the $26^{\text {th }}$ Dynasty", in : GM 154, (1996), 94; A. Awadalla, "Une Ouchebti de why A Heliopolis", in: GM 132, (1993), 8 P.J. Watson , "An Ushabti of theViceroy of Kush Amenhotep", in: JEA 77, (1991) 168; E.B.Hosang, "The shabti of Anen in the Hague", in: JEA76, (1990) , 179; D. Dunham, Nuri II, Nur, I, no.5; Nur.3 no.8 fig .(200); Nur.6, no.9; Nur.8, no.10; Nur.9, no.11, fig .(201); Ku.5 , no 6 ;Nur.27, no 10, fig. (204); Nur. 42, no. 10 Type A; Nur.40, no.10; Nur.58, fig. (205); Nur.39, no .11;Nur.38,no.11, fig.(206); Nur.55, no. 11; Type C; Nur.57, no. 11; Nur.26, no.12, fig.(207); Nur.26, no . 12; Nur .45, no. 12, fig. (208).

${ }^{5}$ D. Dunham, Nuri II , Ku.15, no 3; Ku .16, no .6; fig.(200); Nur.5, no. 12; Nur .10, no .14, fig .(201); Nur.2, no.16, Nur.7, no.15, Nur.4, no.17, fig.(202); Nur.42, no.10 type B, fig. (205).
} 
the word $\check{3} 3$ bty is usually written with a plural demonstrative pronouns (ipw, ipn, iptw, iptn), and the singular spellings do occur mainly on the Kushite specimens. ${ }^{1}$

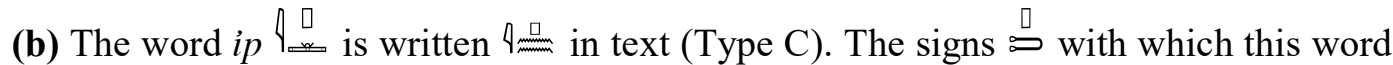
was written in the text of the ushabti of Alexandria, was variant from these signs

could be possible that this sign $\supset$ stands for $\Longleftarrow$, as the verb ip, ipt (counts) was written always with this determinative ${ }^{2}$.

(C, d) The own name (Son of Re name) of the king Senkamanisken ( Imn-skn is unclear in our version. The determinative is abbreviated to strange and unknown drawing, which could be $y$, head of $\mathrm{ox}^{3}$. Additionally the absence of letter ' $\mathrm{n}$ ' in the word $s k(n)$ is also noticed. This name was written with many variants. Its meaning is also unknown. The throne name of the king Senkamanisken is shpr $n R^{{ }^{4}}$. This throne name, shpr $n R$, was attested first probably late of the Ramesside period, particularly in the throne name of the King Ramesses Vli titulary followed the Kushite archaism which was developed at an earlier time and was not based on recent Egyptian inspiration ${ }^{5}$. The researchers ${ }^{6}$ disagreed in relation to the placement of this king among the kings of the Kingdom of Kush, the successors of the Ttwenty-fifth Dynasty. The king Senkamanisken was placed, as the ninth king, following the king Atlanersa, the successor king Tanontamun ${ }^{7}$. Other scholars made him the eighth king, and king Altanersa, the seventh ${ }^{8}$. It is supposed that Senkamanisken was Atlanersa's son and successor. This confirms this that Senkamanisken completed Temple B700 at Gebel Barkal the construction of which was started by Atlanersa. The occurrence of their names in this temple indicates, as does the typological and

\footnotetext{
${ }^{1}$ H.D. Schneider, Shabtis II, 137-138.wšbty is mainly written in te plural, followed by demonstrative pronoun ipn See. D. Dunham, Nuri II, fig.(201-208),except Nur.3,no.8 type B fig.(200); Nur.3,no.8 type C; Nur.6,no.9 fig.(201);Nur.58,no.10 fig.(205);Nur.38,no.11 fig.(206); Nur.26,no.12 fig.(207)

2 Wb.I 66, 1- 23; R. Hannig, Großes Handwörterbuch, Deutsch-Ägyptisch, (Mainz,2000), 1554; H.Lesko, A Dictionary of Late Egyptian, Vol I, (California ,1982), 29; D.M.Doxey, Egyptian Non-Royal Epithets in the Middle Kingdom , A social and Historical Analysis, (Lieden 1988), 178;Urk I, 66,3; 212,5; 16,14 Urk, IV, 119, 10-11;659,5; 927,13-15; 973, 3-4;1119,15-16;1120,1-2; pyr, 590 b; Urk V,124;A. Mariette, Abydos II , (Paris 1880), 54,7 ;P. Reisner, II, E4,pl.8A; C35, pl.6A=W.K. Simpson , Papyrus Reisner II, (Boston 1965), 21;29;H. Goedicke , Königliche Dokumente Aus dem Alten reich, ( Wiesbaden, 1967),17; M. G Daressy, "Fragments de décrets de l'ancien empire", in: ASAE 13, (1913), 109-110. KRI, I, 50,2; , P. E. Newberry, El Berscheh, vol. I, (London, 1893) , 27, pl. XIX; P. Sallier I, 4, 10; A. Gardiner, LEM, 81; F. V. Griffith, The Inscriptions of Siût and Dêr Riféh I, (London, 1889), pl. 7, § 294; P. Montet, , "Les Tombeaux De Siout et Deir Rifeh", in: Kêmi 3,(1930- 1935), 60.

${ }^{3}$ A. H. Gardiner, Egyptian Grammar, Sign-list. F.1, 461.

${ }^{4}$ The Houri name (sh(r?)- t3wy) " Pacifier of two lands"; Nebty name [h'] hr m3`t " [who appears] in $M 3^{\complement} t$ ; the gold Horus name (wsr-phty) " Whose strength is mighty See. D. Dunham and M.F Laming Macadam, JEA 35,147, No. 67; pl. XVI,67; J.U. Beckerath , Königsnamen,307; 130.; G. Reisner, "The Barkal Temples I N 1916" in JEA 5, (1918), 104, fig.2; T.Eide, T.Hägg, R.H. Pierce and L. Török, Fontes Historiae Nubiorum, Textual sours from the history of Middle Nile Region between the Eighth Century $B$ $C$ and the Sixth Century AD, Vol I ( Bergen 1994), 211-212 ;F.L 1. Griffith, "Scenes from a Destroyed Temple at Napata" in: JEA 15, 1929, P1. V.

${ }^{5}$ T. Eide, T.Hägg, R.H. Pierce and L. Török, $F H N$ I, 213

${ }^{6}$ S.Wenig,"Bemerkungen zur Chronologie des Reiches von Meroe", in: MIO 13, (1967), 1-44;M.G, Daressy, "Cartouche d'un Roi Ėthiopien sur un Objet Trouvé á Mit Rahineh", in: ASAE10,(1910), 183-184 ${ }^{7}$ J.U. Beckerath, Königsnamen, 130;165; 307.

${ }^{8}$ The family of the king Senkamanisken consists of the father the king Atlanersa, the mother Malētaralq, Nasalsa the sister wife, Masalaye probably the wife, Amanimalēl the presumed wife, Anlamani the son , Aspelta the son, Henuttakhēbi(t) probably the daughter, Madiquen, the daughter. See. D. Dunham and M.F Laming Macadam, JEA 35, 141-149.
}

\footnotetext{
- 40 - An Ushabti of the King Senkamanisken
} 
topographical relationship between their pyramid graves at Nuri Chronological proximity. Hence it is supposed that Senkamanisken was Altanersa's son and successor and also that he got married to Queen Nasalsa and was thus father of Anlamani and Aspelta ${ }^{1}$.

(e, f) the determinative of the word $s$ (man), and beneath this determinative, a letter $\square$, was written adjacent to the dividing line. However, from the review of the

texts (type $\mathrm{C}$, version VIIA), it is remarkable that it is $r \propto$, which precedes the

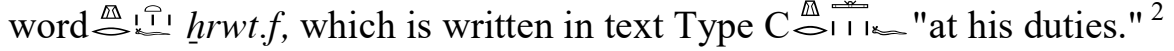

(g) The dependent pronoun $s w$ is written in the text (type C) with $t$ beneath the ideographic sign $\neq$. This was repeated in writing the word $n s w t{ }^{\prime} m_{m}$ in the first $\operatorname{line}^{3}$, but the review of most of the texts of the Kushite ushabtis, these two words were written without $t^{4}$. The expression $m k s w(s y)$ is used in the most of the Kushite ushabtis to call upon the ushabtis to report to the authorities instead of the master. ${ }^{5}$

(h) The verb is written in the text (type C) as follows: but it is mentioned with some the variants 6 . This verb reads $k 3$ or $k 3 i$ and it is an III infirmae verb which means "think about"; "plan", and "say". 7

(I) It is noticed in the end of the construction ip.k $\underline{t}$ (?) (You are counted off...), which precedes the $n w$-clause ${ }^{8} r n w n b$ irt im (at any time to serve there...), the letter $t \leq$, which does not have a meaning or function in this construction. The review of most of the texts of Kushite ushabtis, indicate that this construction has two versions:

V.I: Sing. 2, m. $\rightarrow$ 4 뭉 ip.tw.k Var 4

Sing. 2, f. $\rightarrow$ 品

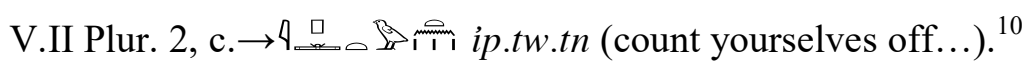

\footnotetext{
${ }^{1}$ T. Eide, T.Hägg, R.H. Pierce and L. Török, FHN I, 212.

${ }^{2}$ See. D. Dunham, Nuri II, Nur.3, no.8, type C, fig.201; Wb III, 391, 8; H.D. Schneider Shabtis II, 143.

${ }^{3}$ D. Dunham, Nuri II , Nur.3, no 8, type C, fig. 201.

${ }^{4}$ See. D. Dunham, Nuri II, fig.201-208.

${ }^{5}$ See. H.D. Schneider, Shabtis II, 145-146.

${ }^{6}$ See. D. Dunham, Nuri II, Nur.3, no.8, type C, fig.201

${ }^{7} \mathrm{~Wb}$ V, 83, 5-6; B 72= A.M Blakman, Middle Egyptian Stories, Part I, (Bruxelles, 1932), 22; A.H. Gardiner Notes on the story of Sinuhe, (Paris, 1916), 38-39; A.de Buck," A note on Sinuhe B.71-72" in: JEA 25, (1939), 100; H. Goedicke, "An Egyptian Claim to Asia" in: JARCE 8, (1969-1970), note. 34; J.P. Allen, Middle Egyptian An Introduction to the Language and Culture of Hieroglyphs, (press, 2000), 19.11, 255; Urk. IV, 138,14; 365,7;269,16; 1542,12;1666,4;1959,17; 1963,11;VII, 48, 14;KRI I, 102,1415; KRI II, 81,1 KRI III,26,1; 69,14; KRI V, 26.1; A. Spalinger, "A Critical Analysis of The " Annals" of Thutmose III", in : JARCE 14,(1977), 51.About mean say. See. H. Lesko, A Dictionary of Late Egyptian, Vol IV, (USA 1989), 30; P. CB.1= A.H. Gardiner, The Chester Beatty Papyrus N. 1: the library of A. Chester Beatty, (London 1931), pl.23, C2V8; P. Orbiney 17, 10=A. H Gardiner, Late-Egyptian Stories, (Bruxelles 1932), 27; P. BM 5645, 5-6= A.H. Gardiner, The Admonitions of an Egyptian Sage from a Hieratic papyrus in Leiden (pap.. Leiden 344 recto), (Hildesheim 1969), 98-99.

${ }^{8}$ See. H.D. Schneider, Shabtis II , 148.

${ }^{9}$ D. Dunham, Nuri II, Nur.6, no.9; Nur.8, no.10; Nur.9, no.11, fig.(201); Nur.5, no 12, fig.( 204); Nur. 10, no. 14; Nur.2, no.16; Nur.7, no 15; Nur. 4, no 17,fig. (202); Nur.24, no .10; Nur.27,no.10; Nur.40, no. 10; Nur.42, no. 10, Type A-B; Nur.58, no.10 fig.(204-205); Nur.38, no. 11 ; Nur.39, no. 11; Nur.55, no.11;Nur.57, no.11, fig. (206-207).

${ }^{10}$ D. Dunham, Nuri II, Ku.16, no.6, fig. (200); Nur. 28, no.11, fig.(206); Nur. 25, no.14, fig. (208).
} 
(K) The beginning of the text inscribed on the back is readable, but the last part is not completely. Can be inferred this lost section through comparing this text with Kushite ushabtis particularly the text Type $\mathrm{C}$ which last part reads:

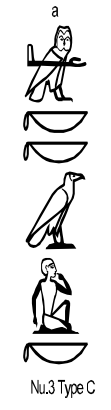

(a) $m k k 3 . k$

Here, you shall say. ${ }^{1}$

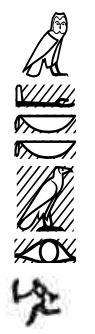

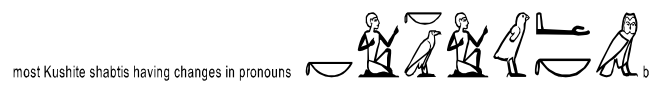

(b) $m k$ wi k3.k

Here I am, you shall say. ${ }^{2}$ Some

(Text from spell of ushabti of the king of Senkamanisken (M.U.A. 1433)

Through comparing these texts, can be read this text as follows $m k k 3$ ir. $i$ " Here, (you) shall say, I shall do it" .. It is noticed that the previous the hieroglyphic signs were written to be read from right to left, all, except for this strange and unclear sign which was written from the left to right. It is noticed that this sign was written close o e hieratic. This passage is 'the call'. During the Second Intermediate Period and New Kingdom, the call is very often supplemented by various terms ${ }^{3}$.The term $m k$ wi $k$ 3. $t n$ var.$k$ is common in the Late Period texts. The prospective $s \underline{d} m . f$, iry. $i$ "I shall do it" was found very ${ }^{4}$ on the Kushite ushabtis meaning "at your orders". 5

${ }^{1}$ D. Dunham, Nuri II, Nur.3, no. (8) Type C, fig. (201).

${ }^{2}$ D. Dunham, Nuri II, Ku.15,no.(3); Ku.16,no.(6); Nur.3,no.(8) Type A,B, fig.(200); Nur.8,no.(10); Nur.9, no.(11); fig.(201); Nur.10,no.(14); Nur.7,no.(15); Nur.2,no.(16); Nur.4, no.(17); fig.(202).

${ }^{3}$ See. H.D. Schneider, Shabtis II, 146-147.

${ }^{4}$ H.D. Schneider, Shabtis II, 148.

${ }^{5}$ Černy and S.I. Groll, A Late Egyptian Grammar, (Rome, 1975), 330; H.D. Schneider, Shabtis I, 146. 


\section{CONCLUSION}

The ushabti of the King Senkamanisken in the Museum of Faculty of Arts, Alexandria University, could be classified into type (III $2 \mathrm{e}$ ). It is one of the types of the ushabtis of the kings of Napata. Its text is identical to the inscriptions of the Napata king's ushabti, in particular to the inscription type $\mathrm{C}$, which is one of the types of the inscriptions of the king Senkamanisken's ushabtis of. It is also noted that the text contains many passages from version VIIA. This version exists commonly on both the Kushite and Egyptian ushabtis.

\section{ACKNOWLEDGMENT}

I am indebt to Prof. Dr. Shouikar Salama in the Faculty of Arts, Alexandria University, for providing me with information and photos of the ushabti of the King Senkamanisken. 


\section{REFERENCES}

-Allen, J.P., Middle Egyptian, An Introduction to the Language and Culture of Hieroglyphs, (press, 2000)

- Awadalla, A., "Une Ouchebti de wxy A Heliopolis", in: GM 132, (1993).

- Aston, D.A. ," The shabti box: a typological study", in: OMRO 74 (1994)

- Beckerath ,J.U., Handbuch der ägyptischen Königsnamen, (Berlin 1984).

- Blakman, A.M., Middle Egyptian Stories, Part I, (Bruxelles, 1932).

-Bares ,L., and Smoláriková. K., "The Shaft Tomb of Iufaa at Abusir. (Preliminary Report for 1995/96)",in: GM 156 (1997),

-Barguet, P., Le liver des morets des Anciens Egyptiens, introduction, traduction, commentaire, (Paris 1967), Translation by Zaika Tabozada, (Cairo 2003),

- Brich,S., "On sepulchral figures " in: Z̈̈S 2, ,(1864); 3 (1865) .

- Budge, E. A. W., The Book of the Dead. An English Translation of the Chapters, Hymns, etc., of the Theban Recension, with Introduction, Vol .I, (London 1951),

-De Buck, A., "A note on Sinuhe B.71-72" in: JEA 25, (1939).

- Capart, J., "Statuettes funéraires égyptiennes" in: $C d E$ 16, (1941)

- Chabas ,F., "Observations sur le chapiter VI du ritual égyptien à propos d'une statuette funéraire du Musé de Langres"in: Maspero,G.(Hg),F.Chabas, CEuvres Diverses 2, ( Paris 1902).

., "Observations sur le chapiter VI du ritual égyptien à propos d'une statuette funéraire du Musé de Langres"in:Mémoires de la Société Historique et Archéologique de Langres, Bd.2 , ( 1863(1862-1877).

- Clére, J.J., Une statuette Funéraire( chabti) à formule anormle ,in: Lesko, L.H. (H g.), Egyptological Studies inHonor of Richard A.Parker. Bd.17-21, (Hanover/ London1986)

- Cerny, J., and Groll S.I., A Late Egyptian Grammar, (Rome, 1975).

- Černý, J., " Le caractère des oushebtis d'après les idées du Nouvel Empire", in : BIFAO 41 (1942).

- Daressy, M.G., Cartouche d'un Roi éthiopien sur un objet trouvé á Mit Rahineh, in: ASAE 10, (1910)

., Fragments de décrets de l'ancien empire, in: ASAE 13, (1913).

- Doxey, D.M., Egyptian Non-Royal Epithets in the Middle Kingdom, A social and Historical Analysis, (Leiden 1988).

- Dunham, D., and Macadam Laming, M.F., "Names and Relationships of the Royal Family of Napata", in: JEA 35, (1949).

., Royal Shawabti Figures from Napata, in: BMFA 49, No. 276, (1951).

., The Royal Cemeteries of Kush, Vol .II, Nuri, (Boston, 1955).

- Eide ,T. , Hägg ,T. , Pierce, R.H., and Török, L. , Fontes Historiae Nubiorum , Textual sours from the history of Middle Nile Region between the Eighth Century B C and the Sixth Century $A D$, Vol I , (Bergen 1994),

- Erman ,A. \& Grapow, H., Wörterbuch de äegyptischen sprache, I- VII, Berlin, 1971; Die Belegstellen 5 Bde, (Berlin, 1940-1959).

- Faulkner, R.F., The Ancient Egyptian Book of the dead, (London 1993),

- _ . . The Ancient Egyptian Coffin Texts, Vol II, (London 1977),

- Gardiner, A.H., Notes on the story of Sinuhe, (Paris, 1916).

., The Chester Beatty Papyrus N. 1: the library of A. Chester Beatty, (London 1931). ., Late-Egyptian Stories, (Bruxelles 1932). ., Late Egyptian Misxcellanies, Bae VII, (Bruxelles, 1937).

., Egyptian Grammar Begin an Introduction to the Study of Hieroglyphs, third edition, (London, 1973).

., The Admonitions of an Egyptian Sage from a hieratic papyrus in Leiden (pap

.Leiden 344 recto), (Hildesheim 1969).

- Goedicke, H., Goedönigliche Dokumente Aus dem Alten Reich, (Wiesbaden, 1967).

., " An Egyptian Claim to Asia" in : JARCE 8, (1969-1970).

- 44 - An Ushabti of the King Senkamanisken 
- Griffith, F.V., The Inscriptions of Siût and Dêr Riféh, I, (London, 1889).

- Hannig ,R., Großes Handwörterbuch, Deutsch-Ägyptisch, (Mainz, 2000).

- Heerma ,Van Voss. M. ,"De sjawabti's en het zandmysterie" in: Phoenix 9 (1963).

., "On the Meaning of the Shipping of Sand by the Shawabtis," in: Proceedings of

the twenty-sixth international Congress of Orientalists 2 ( 1968).

- Himner, I., Figurki uszebti , ( Warschau1959).

- Hosang, F.E.B., "The shabti of Anen in The Hague", in: JEA 76, (1990).

- Kees, H. , Religionsgeschichtliches Lesebuch, Band 10, (Tübngen 1928)

- Keimer ,L., "Das "Sandfahren" der Totenfiguren (wšbtiw) ... "um den Sand der Ostseite zur Westseite zu fahren" : die früheste Erwähnung einer künstlichen Düngung im alten Ägypten" in: OLZ 29 (1926)

- Kitchen, A., Ramesside Inscriptions: Historical and Biographical I-III, (Oxford, 1975- 1980).

- Lesko ,H., A Dictionary of Late Egyptian, Vol .1, (California, 1982).

- Lewis ,P.E., " Is There a Parallel between 1 Samuel 3 and the Sixth Chapter of the Egyptian

Book of the Dead?" in: Journal for Study of the Old Testament 31.3, (2007).

- Newberry, P. E., El Berscheh, vol. I, (London, 1893).

- Noblecourt, Desroches .Chr., Amours et fureurs de La Lointaine. Clés pour la compréhension de symboles égyptiens, ( Paris 1995).

- Mariette, A., Abydos II, (Paris 1880).

- Montet, P., "Les Tombeaux De Siout et Deir Rifeh", in: Kêmi III, (Paris, 1930- 1935).

- Piankoff, A.," Deux variantes du chapitre VI du "Livre des Morts" sur les ouchabtis: ,in: ASAE 49 (1949),

- Reeves, N., "An Unpublished Royal Shabti of the $26^{\text {th }}$ Dynasty", in: GM 154, (1996).

- Schneider, H.D., Shabtis, An Introduction to the history of Ancient Egyptian funerary statuettes, with A Catalogue of the collection of Shabtis in the National Museum of Antiquities at Leiden, (Leiden, 1977).

-.Schlögl, H. A., and Brodbeck, A., Ägyptische Totenfiguren aus öffentlichen und privaten Sammlungen der Schweiz, Freiburg (Schweiz 1990);

(Wiesbaden 1993); ., and Meves-Schlögl ,Chr., Uschebti. Arbeiter im ägyptischen Totenreich, ., And Sguaitamatti,M., Arbeiter des Jenseits. Ägyptische Totenfiguren (Uschebtis), Bd.2 : Zürich Archäologische Hefte,(Zürich, 1977);

- Spalinger, A., "A Critical Analysis of the "Annals" of Thutmose III", in: JARCE, 14 (1977).

- Spanel, D., "Donald, Notes on the Terminology for Funerary Figurines" ,in: SAK 13 (1986),

- Speleers. L., Les figurines funéraires égytiennes , ( Brüssel 1923).

- Simpson W.K., Papyrus Reisner II, (Boston 1965).

- vernus, P., "Une formule des shaouabtis sur un pseudo-naos de la XIIIe dynastie", in: RdE 26 (1974)

- Watson, P.J., "An Ushabti of the Viceroy of Kush Amenhotep", in: JEA 77, (1991).

- Welc, F., "A Fragment of a Shabti from Thebes" ,in: GM 145 (1995).

-Wenig, S., "Bemerkungen zur Chronologie des Reiches von Meroe", in: MIO 13, (1967).

- Wessetzky, V., "Die Uschebti-Formel des "Sandfahrens" und die Himmelsrichtungen", in: MDAIK 37 (1981). 


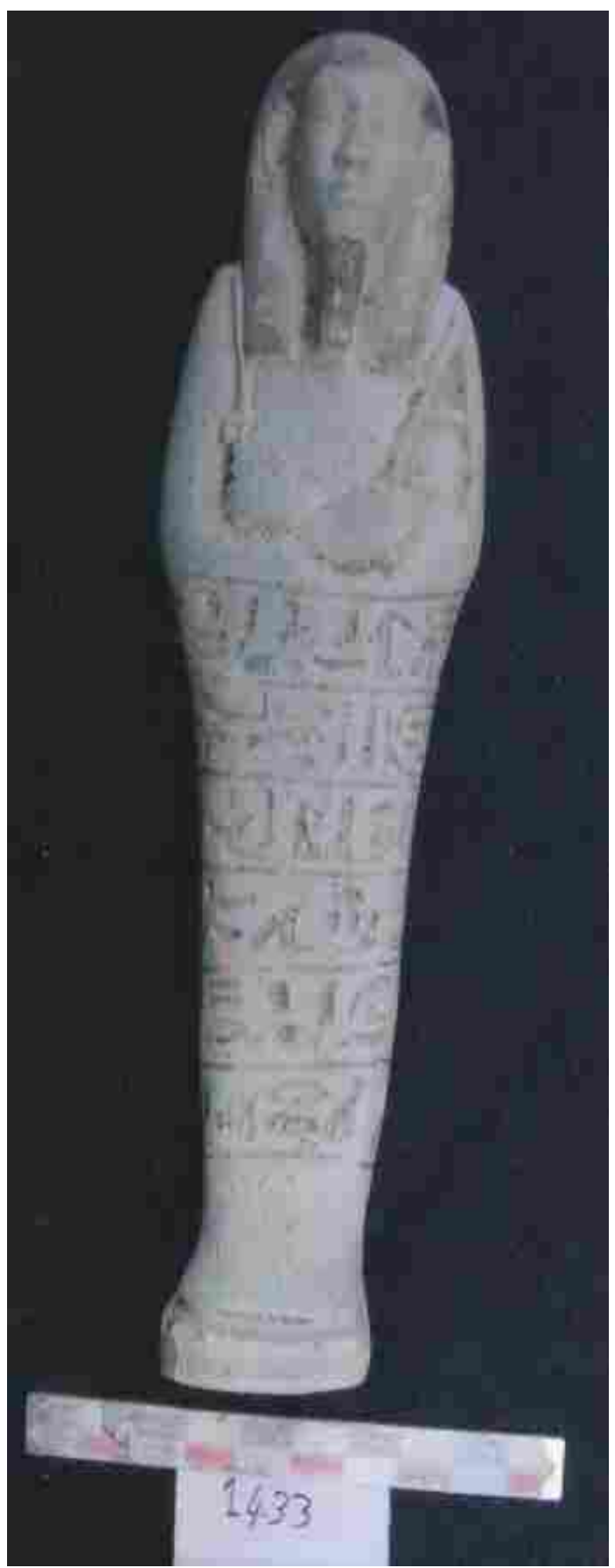

a .

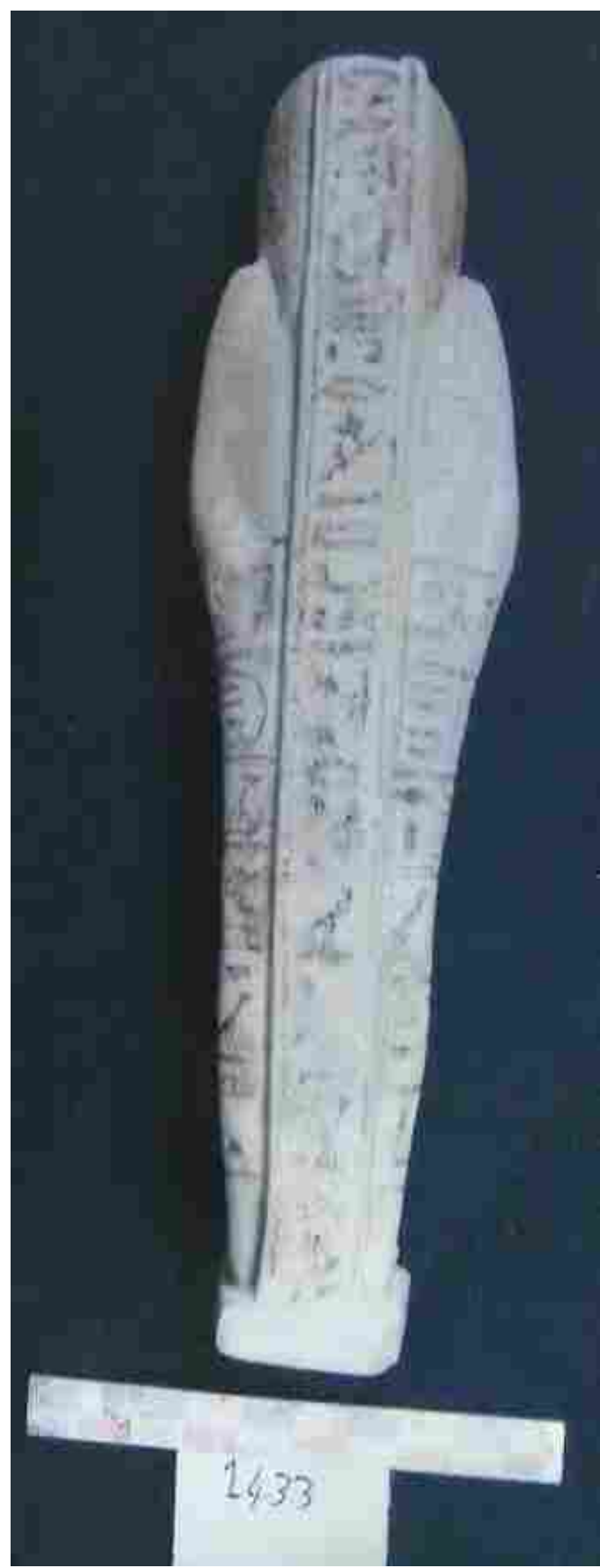

b

Fig. 4 (a.b) shows front and back of the ushabti of the King (M.U.A. 1433) from Nuri. 


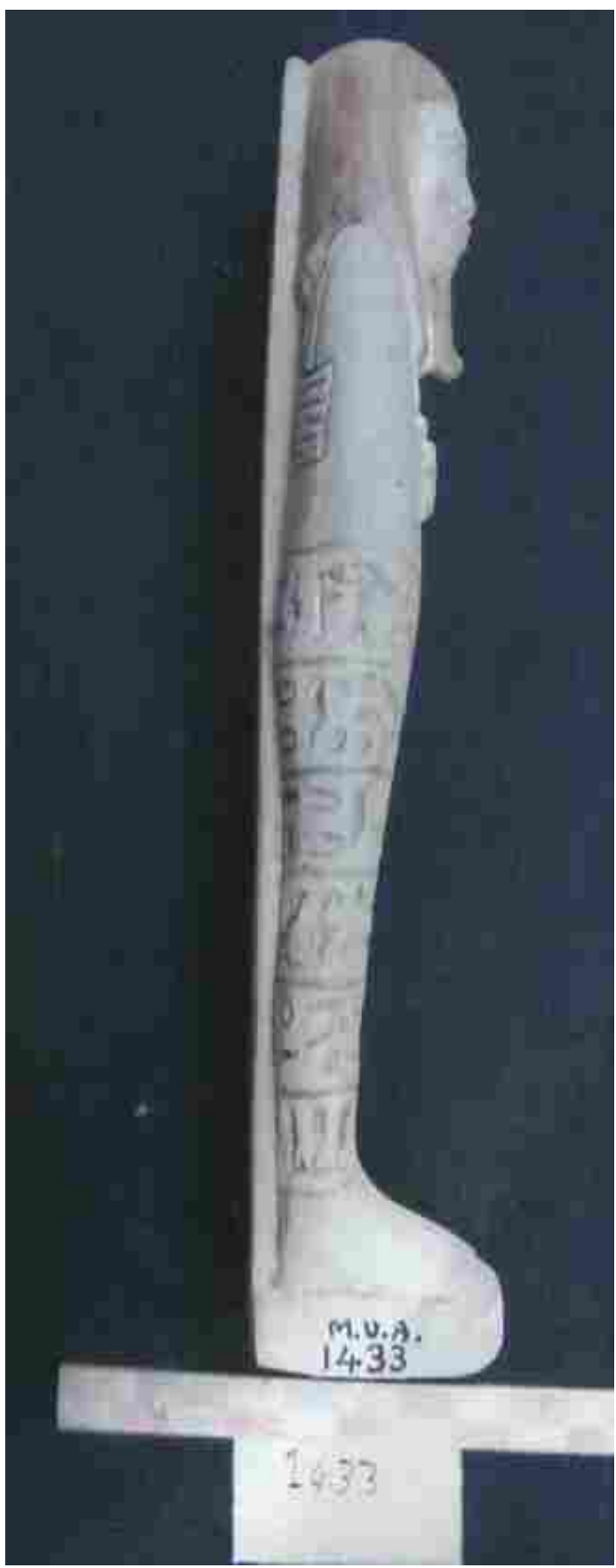

.c

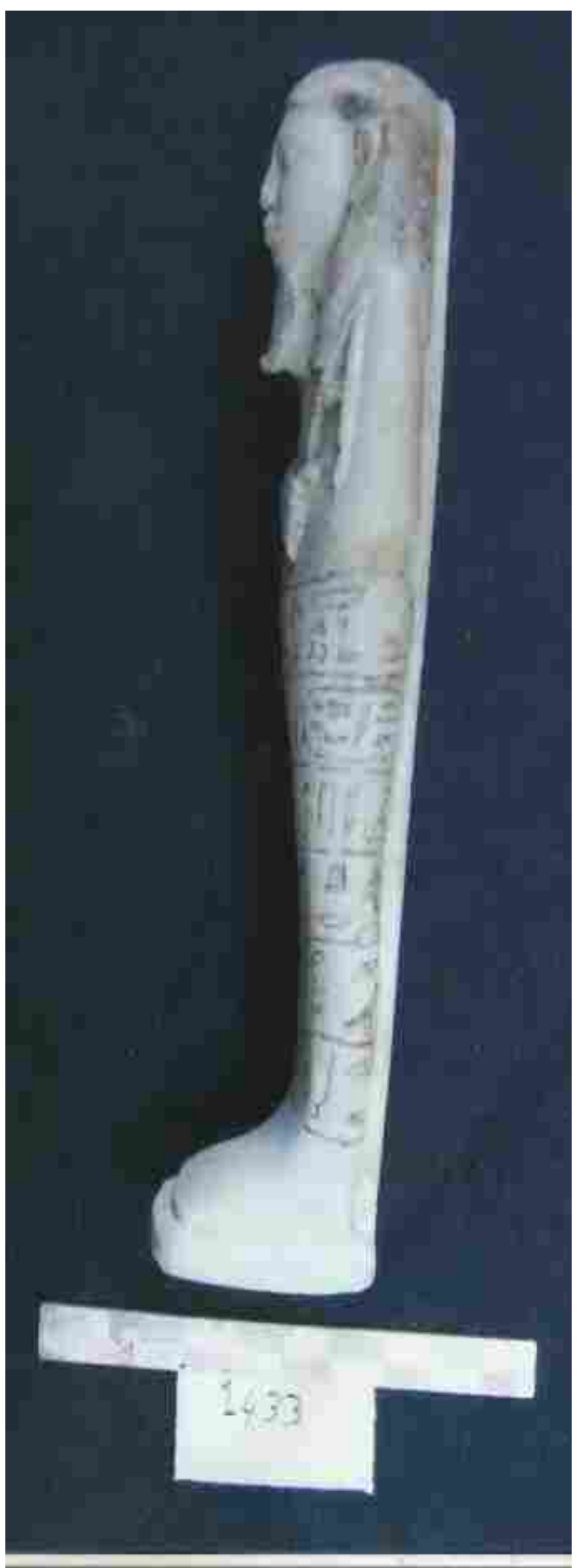

.d

Fig. 5 (c.d) shows the right and left sides of the ushabti of the King Senkamanisken (M.U.A. 1433) from Nuri. 